Teosofia: Indonesian Journal of Islamic Mysticism, Volume 7, Number 1, 2018

\title{
A SPIRITUAL PATH OF A GRAVE DIGGER
}

\author{
Nur Aziz Afandi \\ The Departement of Psychology, The Faculty of Social Sciences and Cultural Studies, \\ The University of Trunojoyo, Madura East Java \\ mas_jiz@yahoo.co.id
}

\begin{abstract}
Heart (qalb) has a higher function than do other sensory organs such as eyes and ears have because heart is the executing part of the soul that changes human spiritual potentiality into actuality. Spiritual actuality of heart such as mukasyafah is possible when it has achieved cleanliness and clarity. Sufism as a spiritual path offers several steps to clean and purify heart. This study explores the spiritual path that has been experienced by a grave digger in the form of mukasyafah towards the sound of complaints and pain from a grave. The data of this essay was gained from interviews with a grave digger in Kediri, East Java. This study concludes that the spiritual path traversed by the grave digger is, among other things, the path of heart which is exercised by the subject by giving help, alleviating sufferings of others, praying for the deceased, and being gentle towards his fellow people. The path of reason is passed by the subject by doing what he obtained from his studying Islam. The path of group is done by having good relations with others. While the path of service is carried out by the subject by giving emphaty to other people who are experiencing distress, giving hands to those who ask for help and giving alms to those in need. The way of dhikr is done by always remembering Allah, realizing and believing in Allah as the provider of the provision and who regulates one's sustenance and being honest in work expecting God's blessing.
\end{abstract}

Keywords. heart, spiritual path, grave digger.

\section{Background}

$\mathrm{R}$ eflecting on the Surah Al-A'raf verse 172, it is understood that humans have transcendental existence before their arrival in this world. It can be concluded from the transcendental or spiritual entity. Muslim theologians interpret that spiritual entity is heart (qalb) (Haq in Ansari, 2003). Frager ${ }^{1}$ also explains that the source of spirituality is heart which is a source of inner light, inspiration, creativity and compassion.

\footnotetext{
${ }^{1}$ Robert Frager, 2014, Psikologi Sufi: Untuk Transformasi Hati, Jiwa dan Ruh. Jakarta: Zaman, p. 26
} 
Transpersonal Psychology also considers that humans have spiritual potential. According to Groff, spirituality is an important dimension of the human soul and a universal scheme. Logotherapy emphasizes this by explaining that spiritual dimension is important in human existence in addition to physical, psychological and socio-cultural. Roberto Assagioli further explained that spiritual is the divine's, as the creator, essence in man and the encouraging aspect of life. According to Victor Frankl, the spiritual dimension is a source of health that has never been affected by illness even if the person is suffering from physical and mental illness. ${ }^{2}$

According to Frankl, humans with their spiritual dimensions allow themselves to carry out spiritual actions, namely responses that are truly realized, for example to take responsibility, accept commitment, make personal choices, and carry out self-transcendence, in order to fulfill human motivation, namely the will to meaning. Frager explained that with spirituality, humans have sincerity, good intentions and compassion. ${ }^{3}$

In addition, spirituality is a connectedness, namely the connection of one's self with God, one's self with others and one self with the universe. In this case, Roy F. Baumeister \& Kathleen D. Vohs explains that connectedness is the essence of meaning. Meaning is not a physical reality. Therefore, someone who does not meet physically the people he or she loves because they have died, he or she can still feel the meaning of their relationship with the people he or she loves. ${ }^{4}$

Humans' spiritual experience makes them leave bad lust and move to the level of al-qurb (close to Allah). With that spiritual experience, the Prophet could experience a compaction of time called at-thayy so that he can travel a distance which should take a long time in a short time like his mi'raj and with mukāsyafah, heaven can be watched by him closely as if it was before his eyes. The Prophet was truly in a very close condition to God which enables him dialogue with God without any angelic intermediary. ${ }^{5}$

Ibn Taimiyah, as quoted by Supriadi, ${ }^{6}$ explains that mukāsyafah is a state in which someone knows what others do not know. According to Al-Ghazali, as quoted by Sutiyono, ${ }^{7}$ mukasyafah, an abstract truth which is called mukasyafah knowledge, is in the realm of ideas, transcendent and real. This knowledge cannot be explained and expressed by words since no sensory is able to touch and no power of reason passes it. Mukasyafah is a vertical truth, from the sky and leads directly to God. In mukasyafah area lies trust, because trust is not solely based

\footnotetext{
${ }^{2}$ Ujam Jaenudin, 2012, Psikologi Transpersonal. Bandung: Pustaka Setia, p. 56

${ }^{3}$ Ibid., p. 65

${ }^{4}$ Ibid.

${ }^{5}$ Ibid.

${ }^{6}$ Lalu Surpriadi, 2013, "Studi Komparatif Pemikiran Tasawuf Al-Gazali dan Ibn Taimiyah". Jurnal Studi Keislaman. Volume 17 Number 2 (Desember).

${ }^{7}$ Agus Sutiyono, 2013, "Ilmu Ladunni dalam Perspektif Al-Ghazali”. Jurnal Pendidikan Islam Vol. 7, Number 2 (Oktober)
} 
on research, but generally appears because of whispers. The strength of heart does not come from humans but from the power of God The Creator in the form of 'inspiration'. Inspiration is knowledge obtained in the resurrection. It is a personal human disclosure that is conveyed to him by God the owner of that knowledge through his mind. Thus the knowledge can only be opened with the key and the path that is spread by Allah to reach the level of the mukasyafah. Imam al-Ghazali stated, quoted by A. Busyairi Harits, that the knowledge produced through inspiration was called Ladunni knowledge. Ladunni knowledge is a knowledge whose achievement is without intermediaries between one's soul and Allah. ${ }^{8}$ It is like the light from a magical lamp that falls into a clear, clean and smooth heart. Sufism appears to cleanse and maintain the purity and cleanliness of the heart as reviewed by Masyhuri saying that one of the objectives of Sufism is to purify heart. Frager ${ }^{9}$ describes Sufism as a spiritual path that can lead one to unity with the Infinite wherever a person is.

The following are the results of the research on the spiritual path experienced by a person that is hearing someone's complaints in the grave.

\section{Research Method}

This study is the result of an open interview with someone who has experienced hearing the voice of someone's complaint in a grave while digging a grave. The collected data is the result of interviews about a person's daily habit which becomes his spiritual path.

\section{Research Outputs}

This research was conducted on Mr. Jono (pseudonym) from Banting village, Pagu District, Kediri Regency. Mr. Jono, 51 years old when the interview was conducted, had 4 children, 1 died at birth. Every day Mr. Jono worked as a bicycle buyer and seller. The income he earned every day was uncertain, sometimes Rp. 50,000 or Rp. 20,000 and sometimes he doesn't even earn any money. Mr. Jono accepted this economic situation even though he was in the category of poor.

Mr. Jono is a generous person. Even though his economic condition was below average, he claimed that he often gave alms to beggars while at the traditional market. In addition, he also used to pay for food for old people who ate with him at inns. He gave his sustenance to God. He accepts and is sincere with his economic situation. In working, he prioritizes honesty, maintaining good relationships with others working as bicycle buyers and sellers. He believed that God governs everyone's sustenance. For him the most important thing is to accept what has become his allotment from Allah. He realized that his destiny in terms of economy was indeed not much. It was better for him to accept and be grateful for what God had written or destined for him.

\footnotetext{
${ }^{8}$ Ibid.

${ }^{9}$ Loc. Cit.
}

Teosofia: Indonesian Journal of Islamic Mysticism, Volume 7, Number 1, 2019 
He was fond of making pilgrimage to the graves of the great people around Kediri. Once he made a pilgrimage to the grave of mbah Prabu (one of old revered person in the past) he was offered by someone more or less a suitcase of money. He firmly refused it, because he believed that someone who offered him was a demon who was tempting his faith and honesty. According to him the money obtained in this way would not bring blessings, even using the money would make him and his family experience havoc. He'd prefer to live hard than living hard in the hereafter. Despite having such experience, Pak Jono remained diligent in making pilgrimages to the tombs of great people around Kediri, especially the graves close to his house.

Pak Jono is a kind person. For the people around him, both his family and neighbors, Pak Jono always gave attention and concerns for them. He was always careful of himself not to make mistakes to others. He realized that the provision he got may come through someone around him. If he was hurt by someone else, he could understand and accept it. He explained that he was treated badly, but he never revenged nor grumbled. He even prayed for that person's goodness. To the people who are experiencing problems he often gave advice so he could immediately solve the problem.

Mr. Jono liked to help others. Whenever someone needed him, he was always ready to help. Especially for a kepaten person (a person one of whose family members dies), even if it is midnight he is always ready to help alleviate people's problem like digging the grave for them. He was actually not an officer to dig a grave, but he was happy to have the opportunity. He explained that everyone would die, so he could help as many people as possible even though it was midnight.

Mr. Jono had an unusual experience which none had while digging a grave. In the middle of the night of Eid al-Fitr, one of his neighbor died. He and his other neighbors held a discussion to decide when the funeral should be done considering the next day, everyone would be busy to perform Eid prayer and silaturrahim. Finally it was decided to bury the neighbor who died in that night after getting approval from the kepaten family. At that time, Mr. Jono and his friends, about 13 people, went to the tomb to dig the grave. Pak Jono helped dig the grave from the beginning until the end of the excavation. Mr. Jono's friends were all by gradually leaving Pak Jono alone to complete the excavation. When Pak Jono was cleaning the bottom of the grave, suddenly Mr. Jono listened to the voice of a man complaining. The voice was very clear from the grave beside Pak Jono's excavation "keluargaku mentolo mentolo men yo yo.. senajan keadaan ngene kok ora teko" (How come my family does not have the heart for me, I am facing this situation but they don't come). The voice was heard three times. Mr. Jono did not run away while listening to the sound, even though his nape hair was all up.

In the morning of the next day, Pak Jono searched for which grave the sound he was listening to when digging a tomb came from. He said that the voice emerged from the grave of Pak Muh. Actually Pak Muh was a diligent person to perform the call to prayers (adzan) during 
his life. According to Pak Jono, Mr. Muh until later died did not have any child. He assumed that the voice sounded because no family had come to do grave pilgrimage 1 day before the feast day (ied al-fitr).

Mr. Jono held his self from telling anyone except people he trusted. He also told the story after 5 days. He told about the sound to all his children. He then advised his children if there were late families at least every Friday, they should recite the Quran for them. His children, who previously did not want to make a pilgrimage to his ancestors' grave, eventually they frequently made a pilgrimage to the graves. He argued that it would be better if people prioritize to make a pilgrimage to their families before others and people far away.

According to Mr. Jono, it is better for people who are still alive to send a prayer to the deceased every Friday, for example by reading the chapter Yasin of the Qur'an because every Friday the dead people were waiting for the prayers from their living family. He suggested that if the family could not visit the grave on Friday night, the good time according to him was Friday morning. Mr. Jono understood that people who die are actually still alive. Only do their bodies die, but not the soul. He gave an example; one of his died neighbor often knocked on the door of his neighbor's house at night. That was because his family never sent prayers to him. With the ability to understand something mystical, Mr. Jono did not admit it. He tended to hide that ability.

\section{Discussion}

Mr. Jono's experience of listening to a man's voice in a cemetery beside the grave he was digging is a spiritual experience in the form of a mukasyafah. He got a truth when digging a grave and he knew what others did not know. Al-Ghazali explained that the truth of muksyafah is abstract. Truth that cannot be expressed in conversation, and no sensory is capable of touching it and not power of mind can reach it.

As explained by Al-Ghazali quoted by Sutiyono, ${ }^{10}$ mukasyafah generally comes in the form of whispers in heart. Such heart power comes from the power of the Ultimate Creator in the form of 'inspiration'. Imam al-Ghazali stated, as quoted A. Busyairi Harits, that the knowledge gained through inspiration is called the knowledge of Ladunni. It is like the light from a magical lamp that falls into a clear, clean and smooth heart. ${ }^{11}$ Sufism arises as an effort to cleanse and maintain the purity and cleanliness of the heart as reviewed by Masyhuri ${ }^{12}$ that one of the objectives of Sufism is to purify heart. Frager ${ }^{13}$ describes Sufism as a spiritual path that can lead one to unity with the Infinite wherever a person is. Then Frager explained that

${ }^{10}$ Agus Sutiyono, Op. Cit., p. 78.

${ }^{11}$ Ibid.

12 Afandi, Nur Aziz \& As'ari, 2017, “Kebebasan Murid Thariqah”. Jurnal Psikologi Integratif Prodi Psikologi UIN Sunan Kalijaga. Vol. 5, Number 1.

13 Robert Frager, Loc. Cit.

Teosofia: Indonesian Journal of Islamic Mysticism, Volume 7, Number 1, 2019 
there were five spiritual paths which included the path of the heart, the path of reason, the path of the group, the path of service and the path of dzikir.

Table 1 depicts the description of some spiritual paths carried out by Mr. Jono, which made him have a clear and clean heart so that it enabled him to experience mukasyafah in the form of knowledge of an occult, namely the voice of someone's complaint in the grave. The spiritual paths are explained as follows.

The first road that was passed by Mr. Jono was the way of heart. This road was passed by Mr. Jono with in te form of a habit of helping others. For example, when one of his neighbor kepaten (one of family members died) as soon as possible even though it was midnight, he went on doing a pilgrimage and helped dig the grave even though he did not get any reward. Towrds someone who is not economically capable he easily eases their burden even though he feels that he will not give much meaning because Mr. Jono himself is a needy person. And to the people who died; ancestors or relatives or whoeverm, he realized they need prayer, he will pray for them. In addition, he treat his children gently, never abused his children. With that way, he felt his children obeyed him.

The next path is the path of reason. Mr. Jono attended study circles learning Islam which were taught by the guardian of Allah (waliyullah) in Kediri. In the case of grieving for example, he remembered the words of a wise person that if he got sustenance, he should not forget to reduce it by giving charity. He liked it when giving alms to elderly he met at the market who couldn't afford something. He said that he liked to treat them food with his actually poor economic condition. But he was willing to do that. This is a manifestation of what he got when attending routine study circles.

The third path is grouping. When attending a regular circle for studying Islam by a guardian (wali) of Allah, he would gather with his friends even though sometimes he went alone, but then he met his entourage there. When together with people around, Pak Jono always strove to maintain good relations by not making mistakes. To maintain a good relationship, Mr. Jono was often spoke carefully and avoided quarreling with people around him. For him to give in and pray for those who are at odds with him were the best way. He also had a grudge against anyone because he claimed that he had no problems with anyone. His relationship was good with everyone.

The next one is the path of service. This path was done by Mr. Jono by giving attention to other people who were in difficult situation, such as those whose one of their family died by helping dig the grave regardless of the time. Easing the burden of people asking for help was done by giving advice to someone having problems, giving alms to those who are in need.

The next path taken by Mr. Jono was dzikir. In an effort to find sustenance, he always started by praying and giving up everything to God. He did not regret when he was not earning money because he was aware and trusted that God is the Provider of the provision and who 
regulates one's sustenance. He also sincerely accepted his lack of economic condition. For him it is better to be difficult in the world than to be difficult in the hereafter. Although he had once had the opportunity to get a lot of money from the late Mbah Prabu while when he performed a pilgrimage at his tomb, he did not take the money because he realized that the money was not from Allah but from satan. As a person, Mr. Jono is humble even though he has abilities that others do not have such as watching and listening to something magical. It can be said that $\mathrm{Mr}$. Jono had done a lot of things to other people, but he was not proud of himself with what he had done.

\section{Conclusion}

Mukasyafah can be experienced by someone having a clear heart. The cleanliness of one's heart can be achieved by a spiritual path; tasawuf.

The grave digger experienced mukasyafah because he had taken spiritual paths, among others:

a. The path of heart: The first path was taken by Mr. Jono by giving help, alleviating suffering of others, praying for the dead, and being gentle with his fellow people. ${ }^{14}$

b. The path of reason: The path of reason was passed by Mr. Jono by following the religion study circle and doing what was obtained from there.

c. The group path. In this path of grouping, Mr. Jono joined religious study circle activities together with those around him. In addition, he strived to maintain good relations by not making mistakes, being careful in speaking and avoiding disputes with people around him. He liked to give and pray for those who are at odds with him.

d. The service path. The path of service was taken by Mr. Jono by giving attention to other people experiencing difficulties, alleviating the burden of the people who asked for help by giving advice if someone asked for advice to solve their problems, giving alms to those who are in need.

e. The path of dzikir: on this last path, Mr. Jono always remembered Allah, therefore he always started his work by praying and giving up everything to Allah. He realized and trusted God as the Provider of provision and who governs one's sustenance. He was honest in his work because of expecting blessing from God. Mr. Jono is a humble person even though he has abilities that others do not have.

\section{Suggestions}

Based on the above research, the researcher suggested to the subject of this research to keep his spiritual quality, it is even better if he could increase his spiritual quality with a full

\footnotetext{
${ }^{14}$ Nikmaturrahmah and Ahmad Musyafiq, 2017, "Sufistic Values in Suryomentaram Kawruh Jiwo". Teosofia: Indonesian Journal of Islamic Mysticism, Vo. 6, Number 2.
}

Teosofia: Indonesian Journal of Islamic Mysticism, Volume 7, Number 1, 2019 
guidance from the teacher continuously. The researcher also suggested to next researchers to carry out the same research using qualitative approach to find out what was the most dominant spiritual paths carried out by a subject so that he or she could reach the mukasyafah.

\section{Bibliography}

Afandi, Nur Aziz \& As'ari, Muhammad (2017) Kebebasan Murid Thariqah. Jurnal Psikologi Integratif Prodi Psikologi UIN Sunan Kalijaga. Vol. 5, Nomor 1, 2017

Ansari, Zafar Afaq (2003) Al-Quran Bicara tentang Jiwa. Bandung: Arasy

Frager, Robert (2014) Psikologi Sufi : untuk Transformasi hati, Jiwa dan Ruh. Jakarta: Zaman Jaenudin, Ujam (2012) Psikologi Transpersonal. Bandung: Pustaka Setia

Surpriadi, Lalu (2013) Studi Komparatif Pemikiran Tasawuf Al-Gazali dan Ibn Taimiyah. Jurnal Studi Keislaman. Volume 17 Nomor 2 (Desember)

Sutiyono, Agus (2013) Ilmu Ladunni dalam Perspektif Al-Ghazali. Jurnal Pendidikan Islam Vol. 7, Nomor 2 ( Oktober)

Table 1. Interview Summary

\begin{tabular}{cllll}
\hline No & \multicolumn{1}{c}{ Statement } & $\begin{array}{l}\text { Gesture and } \\
\text { Behaviour }\end{array}$ & Towards & \multicolumn{1}{c}{$\begin{array}{c}\text { Spiritual } \\
\text { Paths }\end{array}$} \\
\hline 1 & $\begin{array}{l}\text { I do not dare to tell this experience to } \\
\text { anyone except after five days ... I am } \\
\text { afraid people think I scare them ... that } \\
\text { kind of experience I do not like to tell } \\
\text { anyone except friends .. }\end{array}$ & Careful & others & $\begin{array}{l}\text { The group } \\
\text { path }\end{array}$ \\
\hline 2 & $\begin{array}{l}\text { In my opinion, than making pilgrimage } \\
\text { to some far graves, it's better to make a } \\
\text { pilgrimage to your own family.... }\end{array}$ & $\begin{array}{l}\text { Preferring } \\
\text { family to pray } \\
\text { for }\end{array}$ & $\begin{array}{l}\text { Late } \\
\text { family }\end{array}$ & The heart \\
path
\end{tabular}




\begin{tabular}{|c|c|c|c|c|}
\hline 5 & $\begin{array}{l}\text { Bismillah ... basically I don't do bad } \\
\text { things to people ... if there are cigarettes } \\
\text { we smoked together }\end{array}$ & $\begin{array}{l}\text { being kind } \\
\text { and attentive } \\
\text { to others }\end{array}$ & Others & $\begin{array}{l}\text { The group } \\
\text { path }\end{array}$ \\
\hline 6 & $\begin{array}{l}\text { I don't have any problem with people ... } \\
\text { if I get bullied, I just smile ... I've } \\
\text { worked almost } 1 \text { month and was } \\
\text { promised to get salary of my work but I } \\
\text { still don't get the salary yet and I just } \\
\text { smile.. }\end{array}$ & $\begin{array}{l}\text { Accepting and } \\
\text { understanding }\end{array}$ & Others & $\begin{array}{l}\text { The group } \\
\text { path }\end{array}$ \\
\hline 7 & $\begin{array}{l}\text { I have asked (my salary) } 1 \text { or } 2 \text { times, if } \\
\text { I'm still not given, that's fine... I'm sure } \\
\text { God will replace ... so people don't have } \\
\text { to have a tense mind ... just relax ... } \\
\text { Allah will replace }\end{array}$ & Tawakkal & Allah & Dhikr path \\
\hline 8 & $\begin{array}{l}\text { I am a person who is easy to help ... to } \\
\text { anyone including the kepaten person } \\
\text { (one of the family members died) }\end{array}$ & helpful & Other & $\begin{array}{l}\text { Heart and } \\
\text { service paths }\end{array}$ \\
\hline 9 & $\begin{array}{l}\text { I got no fee for digging a grave ... Allah } \\
\text { pays in the end. }\end{array}$ & Ikhlas & Allah & $\begin{array}{l}\text { The path of } \\
\text { hearth, } \\
\text { service and } \\
\text { dhikr }\end{array}$ \\
\hline 10 & $\begin{array}{l}\text { Later we will go home (home after } \\
\text { death) ... if we don't do takziyah (visit } \\
\text { for condolance) them now ... do people } \\
\text { do takziyah later when we die... }\end{array}$ & $\begin{array}{l}\text { Preparing for } \\
\text { death }\end{array}$ & Himself & $\begin{array}{l}\text { The service } \\
\text { path }\end{array}$ \\
\hline 11 & $\begin{array}{l}\text { as I heard someone died, I went... even } \\
\text { though it was night ... whoever was the } \\
\text { one who was in trouble I do still } \\
\text { takziyah ... }\end{array}$ & Helpful & Others & $\begin{array}{l}\text { The path of } \\
\text { heart and } \\
\text { service }\end{array}$ \\
\hline 12 & $\begin{array}{l}\text { The point is to ask God ... everytime I } \\
\text { go working I read syahadat and istighfar } \\
\text {... }\end{array}$ & Tawakkal & Allah & $\begin{array}{l}\text { The path of } \\
\text { dhikr }\end{array}$ \\
\hline 13 & $\begin{array}{l}\text { (I have) } 4 \text { (children) and } 1 \text { died at birth } \\
\ldots \text { my child, who died if I did not do } \\
\text { ziarah, usually showed up ... now he is } \\
\text { big ... }\end{array}$ & $\begin{array}{l}\text { Visible to } \\
\text { supranatural } \\
\text { existance }\end{array}$ & $\begin{array}{l}\text { Dead } \\
\text { people }\end{array}$ & $\begin{array}{l}\text { The heart } \\
\text { path }\end{array}$ \\
\hline 14 & $\begin{array}{l}\text { Here, I have a story, my child and wife } \\
\text { got accident. The accident was normal } \\
\text { but how come they were not concsious } \\
\text { for a long time. Well, my friend invited } \\
\text { Gus Mik for a cure. And I invited Him } \\
\text { to get in ICU room. }\end{array}$ & Attentive & Family & $\begin{array}{l}\text { The path of } \\
\text { heart and } \\
\text { service }\end{array}$ \\
\hline
\end{tabular}

Teosofia: Indonesian Journal of Islamic Mysticism, Volume 7, Number 1, 2019 


\begin{tabular}{|c|c|c|c|c|}
\hline \multirow[t]{4}{*}{15} & $\begin{array}{l}\text { I want to buy (massage) oil for sick } \\
\text { child and wive. He, Kyai, said that the } \\
\text { oil costs } 500 \text { thousand. I replied "yes } \\
\text { Gus, it's okay. I am ready to pay any } \\
\text { amount." }\end{array}$ & \multirow[t]{4}{*}{ Trust } & \multirow[t]{4}{*}{ teacher } & \multirow[t]{4}{*}{$\begin{array}{l}\text { The path of } \\
\text { reason }\end{array}$} \\
\hline & $\begin{array}{l}\text { Gus mik asked me to make cok bakal } \\
\text { (an offering for spirits) in the place } \\
\text { where the accident occured and he said } \\
\text { that the next day my child would be } \\
\text { conscious but my wife would be } \\
\text { critical. }\end{array}$ & & & \\
\hline & $\begin{array}{l}\text { After I got cok bakal and I put it in the } \\
\text { place, my son was finally conscious. }\end{array}$ & & & \\
\hline & $\begin{array}{l}\text { But my son was deteroriating and back } \\
\text { unconscious again, because the cok } \\
\text { bakal was put in the grave without cups. } \\
\text { And I try to find the cok bakal again, } \\
\text { my child woke up immediately. My } \\
\text { wife was also conscious and fine }\end{array}$ & & & \\
\hline 16 & $\begin{array}{l}\text { I'm a fool, can't read... ish, I'm a fool, I } \\
\text { don't understand anything. I am affraid } \\
\text { people would think I am a smart person. }\end{array}$ & Humble & Others & $\begin{array}{l}\text { The path of } \\
\text { dhikr }\end{array}$ \\
\hline 17 & $\begin{array}{l}\text { That is, every Friday night or Friday } \\
\text { morning the yasin is read for dead } \\
\text { people because they are actually still } \\
\text { living there. Their bodies in this world } \\
\text { are dead, but their spirits there are still } \\
\text { alive. So they need a recitation from } \\
\text { their family. }\end{array}$ & Praying & $\begin{array}{l}\text { Dead } \\
\text { people }\end{array}$ & $\begin{array}{l}\text { The path of } \\
\text { heart }\end{array}$ \\
\hline 18 & $\begin{array}{l}\text { Yes, you must be confident, sure, you } \\
\text { must be really sure, my brother. } \\
\text { Because God will grant us what we } \\
\text { want if we really believe in Him. }\end{array}$ & Believe & Allah & $\begin{array}{l}\text { The path of } \\
\text { dhikr }\end{array}$ \\
\hline 19 & $\begin{array}{l}\text { I've once seen a lot of money at the } \\
\text { tomb of Prabu. But I don't take it, mas. } \\
\text { I don't want it because that's the devil's } \\
\text { money. Rezki must be lawful (halal) }\end{array}$ & Honest & $\begin{array}{l}\text { Earning } \\
\text { money }\end{array}$ & $\begin{array}{l}\text { The path of } \\
\text { dhikr }\end{array}$ \\
\hline 20 & $\begin{array}{l}\text { I'm not interested, mas. Because it's the } \\
\text { same as debt, we must return it. It is the } \\
\text { same with people who are looking for }\end{array}$ & $\begin{array}{l}\text { Aware of } \\
\text { consequence }\end{array}$ & Himself & $\begin{array}{l}\text { The path of } \\
\text { heart and } \\
\text { dhikr }\end{array}$ \\
\hline
\end{tabular}


pesugihan (wealth with the help of evil spirits), if they cannot pay sacrifice, the children and our generation are their target. Because it will pass from generation to generation.

There are cases of people like that. His father was looking for pesugihan, when the father had died and was not continued by his son, the child's life was very heavy. Even though he seemed to be living rich, he had 3 trucks and acres of rice fields but it was hard for them to eat.

\begin{tabular}{|c|c|c|c|c|}
\hline 21 & $\begin{array}{l}\text { No problem, mas. It is okay to have } \\
\text { burden in this world, as long as we dont } \\
\text { have it in the hereafter. We should } \\
\text { prepare our lives ther. } \\
\text { I dont want big things, the main poin we } \\
\text { always ask Allah. }\end{array}$ & \begin{tabular}{l} 
- Being \\
compliant \\
nd accepting \\
- \\
\multicolumn{1}{c}{ Reme } \\
mbering \\
death \\
- surrender
\end{tabular} & $\begin{array}{l}\text { - Destiny } \\
\text { - Death } \\
\text { - Allah }\end{array}$ & $\begin{array}{l}\text { The path of } \\
\text { dhikr }\end{array}$ \\
\hline 22 & $\begin{array}{l}\text { Only salvation and health. For wealth, I } \\
\text { never ask. The important thing is } \\
\text { whenever we work we will gain } \\
\text { enough, that's it }\end{array}$ & $\begin{array}{l}\text { - Preferring } \\
\text { the hereafter }\end{array}$ & hereafter & $\begin{array}{l}\text { The path of } \\
\text { dhikr }\end{array}$ \\
\hline 23 & $\begin{array}{l}\text { I have no problem with anyone and will } \\
\text { never have, mas. Because I am } \\
\text { compliant }\end{array}$ & compliant & others & $\begin{array}{l}\text { The path of } \\
\text { group }\end{array}$ \\
\hline 24 & $\begin{array}{l}\text { What is that for? I dont revenge and I } \\
\text { dont like it. }\end{array}$ & No revenge & others & $\begin{array}{l}\text { The path of } \\
\text { group }\end{array}$ \\
\hline 25 & $\begin{array}{l}\text { Everyone will surely die. Now or later } \\
\text { we will die. I am ready to die now. If } \\
\text { we are dare to live, we should be dare to } \\
\text { die }\end{array}$ & Ready to die & death & $\begin{array}{l}\text { The path of } \\
\text { dhikr }\end{array}$ \\
\hline 26 & $\begin{array}{l}\text { Oh, accepting what is destined for us by } \\
\text { Allah. If our porsion is such, we should } \\
\text { just accept it. My plate is small, so I feel } \\
\text { grateful for whatever it is. }\end{array}$ & $\begin{array}{l}\text { Accepting } \\
\text { happily for } \\
\text { what is given } \\
\text { Grateful } \\
\text { accepting the } \\
\text { destiny }\end{array}$ & Allah & $\begin{array}{l}\text { The path of } \\
\text { dhikr }\end{array}$ \\
\hline 27 & Giving alms so we will get blessing. & $\begin{array}{l}\text { Giving alms } \\
\text { generous }\end{array}$ & others & $\begin{array}{l}\text { The path of } \\
\text { heart }\end{array}$ \\
\hline
\end{tabular}




\begin{tabular}{|c|c|c|c|c|}
\hline & $\begin{array}{l}\text { So if I got some amount of money, I pay } \\
\text { for old people when I eat in inns. I } \\
\text { usually give older people, not young. } \\
\text { Many old people beg in the market. } \\
\text { Giving } 5000 \text { and cigarete is enough to } \\
\text { make them happy. I often give beggars } \\
\text { and old people. } \\
\text { Remember, if you earn a lot, dont forget } \\
\text { to reduce it. }\end{array}$ & & & \\
\hline 28 & $\begin{array}{l}\text { I gave them good suggestions... (I pray } \\
\text { them) that they are guided to the right } \\
\text { path and I entertained them ... I said (to } \\
\text { them) don't think of something too } \\
\text { deeply... at least we still have something } \\
\text { to eat ... something to entertain yourself } \\
\ldots \text {... to relieve stress ... to make coffee ... } \\
\text { Then he asked me for a wife and then I } \\
\text { found him a wife and finally he died }\end{array}$ & advicing & Others & $\begin{array}{l}\text { The path of } \\
\text { heart and } \\
\text { service }\end{array}$ \\
\hline 29 & $\begin{array}{l}\text { to people who do not agree with me, I } \\
\text { read fatihah } 3 \text { times } \\
\text { The important thing is that if we don't } \\
\text { do wrong, , we will not be mistaken by } \\
\text { anyone ... }\end{array}$ & $\begin{array}{l}\text { Praying for } \\
\text { those who } \\
\text { disagree }\end{array}$ & others & $\begin{array}{l}\text { The path of } \\
\text { group }\end{array}$ \\
\hline 30 & $\begin{array}{l}\text { Because I'm a bicycle seller, we need } \\
\text { others to get rejeki or provision. } \\
\text { Considering that our provision may } \\
\text { come from other people, it is not much } \\
\text { what we spend paying people in } \\
\text { canteen. I know everyone in this village }\end{array}$ & $\begin{array}{l}\text { Awaring that } \\
\text { provision } \\
\text { comes from } \\
\text { others }\end{array}$ & $\begin{array}{l}\text { Others } \\
\text { provision }\end{array}$ & $\begin{array}{l}\text { The path of } \\
\text { group }\end{array}$ \\
\hline 31 & $\begin{array}{l}\text { To the person in difficulties I pray for } \\
\text { them hopefully their problems can be } \\
\text { solved soon, I wish them good luck and } \\
\text { health as well. }\end{array}$ & $\begin{array}{l}\text { Fond of } \\
\text { praying for } \\
\text { others }\end{array}$ & Others & $\begin{array}{l}\text { The path of } \\
\text { heart }\end{array}$ \\
\hline 32 & $\begin{array}{l}\text { If someone sells something to you it } \\
\text { means it is your blessing ... if someone } \\
\text { sells the thing to me, it means for me. } \\
\text { I don't have any anger. I live in } \\
\text { harmony.. if it's not meant for me, even } \\
\text { if the price is raised, it's still not for me. } \\
\text { each person has their own provision. If } \\
\text { it is meant for me, it won't go anywhere }\end{array}$ & $\begin{array}{l}\text { - Being } \\
\text { honest in } \\
\text { work } \\
\text { - surrender }\end{array}$ & Allah & $\begin{array}{l}\text { The path of } \\
\text { dhikr }\end{array}$ \\
\hline 33 & I go every Friday to kramatan & $\begin{array}{l}\text { Educating } \\
\text { children }\end{array}$ & family & $\begin{array}{l}\text { The path of } \\
\text { heart }\end{array}$ \\
\hline
\end{tabular}


I told all of my children the stories, now my children want to go to kramatan.. I tell my children that died people every Friday open their house doors, ask for qur'anic recitation, I tell that to all my children.

34 I have never scolded a child, I told the gentle Children The path of child one or two times if it was not and family heart and followed already ... service I choose to be quiet if there is a problem with the child .. At most, I just order them to do this and that...

35 My children are obedient I advise them to do good
Advising to do good
Children and family
The path of heart and service 